\title{
Effects of Graphene Addition on Negative Active Material and Lead Acid Battery performances under Partial State of Charge Condition
}

\author{
Witantyo $^{1}$, Oxi Putra Merdeka ${ }^{1}$, Lia Amalia ${ }^{1}$, Lukman Noerochim ${ }^{2}$, Heru Setyawan ${ }^{3}$, \\ Abdullah Shahab ${ }^{1}$, Suwarno Suwarno ${ }^{1, *}$ \\ ${ }^{1}$ Department of Mechanical Engineering, ITS, Surabaya 60111, Indonesia \\ ${ }^{2}$ Department of Material and Metallurgical Engineering, ITS, Surabaya 60111, Indonesia \\ ${ }^{3}$ Department of Chemical Engineering, ITS, Surabaya 60111, Indonesia \\ *E-mail: warno@me.its.ac.id
}

doi: $10.20964 / 2021.08 .27$

Received: 1 March 2021 / Accepted: 10 June 2021 / Published: 30 June 2021

The use of carbon materials as additives in lead-acid battery electrodes is known to have a positive effect on battery performance via the increase in the battery cycle life. However, every type of carbon material has a different impact. Furthermore, the mechanism of performance improvement must be clarified. In the present work, graphene was added into a negative active material (NAM) used in a battery cell. The cell was tested under a partial state of charge condition at an extreme discharge cycle. The NAM plates were also tested using cyclic voltammetry and electrochemical impedance spectroscopy. The results showed that the graphene additive increases the conductance of the NAM. Scanning electron images showed refined particle sizes of the sulfates. A combination of decreasing the internal resistance of the battery and particle refinement of the NAM was found to be responsible for the improved cycle life.

Keywords: Graphene, Lead-acid battery, Life cycle, PSOC test

\section{$\underline{\text { FULL TEXT }}$}

(C) 2021 The Authors. Published by ESG (www.electrochemsci.org). This article is an open access article distributed under the terms and conditions of the Creative Commons Attribution license (http://creativecommons.org/licenses/by/4.0/). 